\title{
Long-Term Fertility Development in Baltoscandia
}

\author{
KALEV KATUS \\ Professor and Director \\ Estonian Interuniversity Population \\ Research Centre \\ Tallinn, Estonia
}

\begin{abstract}
The article is a short overview of some principal fertility trends in Estonia, Finland, Latvia, Lithuania, and Sweden. Those countries, from the historical perspective, have been characterized by relatively early start of demographic transition. Also, in period of fertility transition, these countries have demonstrated rather similar developments and formed one of the most homogenous subregions in Europe in this respect. However, post-transitional fertility development has been rather desynchronized between the named countries: not only the Baltic-Scandinavian differences but also the difference between Estonia-Latvia and Lithuania as well as between Sweden and Finland has become important. The noticeable part of this heterogeneity is explained by the relatively stable cohort fertility in Estonia and Latvia while in Finland, Lithuania, and Sweden the birth cohorts have had rather divergent outcomes of their fertility careers. Currently the Baltic countries are characterized by sharp fertility decrease, accompanied by the deep structural transformation of the fertility pattern. The intense aging of fertility, particularly because of postponement of the first child, is in contrast to much smoother development of the same kind in Finland and Sweden.
\end{abstract}

Keywords: fertility trends, Finland, Estonia, Latvia, Lithuania, Sweden, Baltic Sea Area

The post-transitional fertility pattern has been prevailing even among the pioneering nations of the demographic transition for just three generations, and in most other cases it has a much shorter history. From a theoretical perspective, this is definitely too short a period for a comprehensive understanding of modern fertility development. Data from much lengthier periods are needed to exhaustively analyze principal questions like timing and the mechanism of re-establishment of replacement fertility, the development of relationships between marital, sexual, and reproductive behavior, the balance and age-pattern of child birth and other pregnancy outcomes, the spread of genetic diseases under a low-fertility regime, etc., and to draw up long-term trends of post-transitional fertility and separate them from various short-term fluctuations. Nevertheless, a three-generational period is long enough to reach some preliminary conclusions. The following article is a short overview of some principal fertility trends in the Baltoscandian countries, namely in Estonia, Finland, Latvia, Lithuania, and Sweden. Those countries, from a historical perspective, have been characterized by a relatively early start of demographic transition, and, thus, a longer predominance of the modern fertility pattern. However, for most of that period the three Baltic countries had been forced to belong to the Soviet empire, while Finland and Sweden remained on the other side of the Iron Curtain. This historical fact gives additional interest to a comparison of the fertility trends in the aforementioned countries. 


\section{Demographic transition: some variation in timing}

Despite the fact that demographic transition is a universal process, its different timing has had a tremendous impact on population, and correspondingly, on the social and human development of the European nations in general. The influence referred to is continuously of great importance, its impact manifesting itself particularly through the population age structure. There is a strong argument for considering methodologically as well as in practical terms the timing of the demographic transition as an important starting point for the analysis of any long-term trend in population development. In this context, the European marriage pattern is widely acknowledged as the first major phenomenon introducing the principal differentiation of demographic development between European nations, and particularly having an impact on the timing of the fertility transition in later stages. The concept of the European marriage pattern has been elaborated by John Hajnal and his article on this subject has became one of the most cited research articles in demography, one which should not be overlooked in any work on long-term population trends (Hajnal 1965).

The European marriage pattern divided Europe roughly into two parts. In addition, some smaller geographical areas with more or less definitely concentrated areas with common features were formed. The general division along the St. Petersburg-Triest line is well documented and widely accepted. Much less research has been carried out on heterogeneity within both subregions, witnessing or not witnessing a spread of the European marriage pattern. Both components are important in outlining the demographic development in the region of Baltoscandia.

On one hand, the Baltic countries and Finland in the north formed the eastern boundary of the European marriage pattern. In this context two features are worth emphasizing. First, the Hajnal line in this part of Europe very clearly ignored the political and administrative borders of the time. When the pattern was first introduced, Finland was a part of Sweden, Estonia and Northern Latvia belonged to Russia and the eastern part of Latvia as well as Lithuania formed a part of Poland. Nevertheless, the new marriage pattern was introduced somewhat earlier in Estonia and developed further (Palli 1988, 1997) compared to Finland or Lithuania for example. This occurred then in a country belonging politically to Russia which never developed the European marriage pattern. Secondly, the Hajnal line in this part of Europe evolved later into the largest difference in fertility transition timing between two neighboring countries. This difference, concerning Estonia and Russia in particular, is estimated to be up to half a century (Katus 1990; Vishnevski and Volkov 1983) exceeding in length, for example, another wellknown division of that type, the one between the Flemish and Walloon populations in Belgium (Lesthaeghe 1977; Coale and Treadway 1986). On the other hand the Baltic countries also differ from the Central European countries to the south. The differentiation was less evident in the era when the European marriage pattern was spreading but became more pronounced later during fertility transition. In this way the southern border of Baltoscandia has also been taking a form which has probably been most indistinct in the western part, between the Scandinavian countries and Netherlands/Germany. Nevertheless, the timing of fertility transition shows the differentiation also at this border.

Fertility transition and its timing in Europe have been most comprehensively studied within the framework of the Princeton Project. Measuring fertility with specifically defined general indices (fertility rates, standardized to the Hutterites fertility schedule), the province-level analyses cover most of the European countries (Coale and Watkins 1986). Additionally, several country case studies have been carried out concerning the region currently of interest, for Sweden (Hofsten and Lundström 1976; Royal Ministry for Foreign Affairs 1974) and Finland (Fougstedt 1977; Notkola 1989; Lutz 1987; Strömmer 1969). Using the methodology of the Princeton Project, similar indices have been calculated for Estonia (at the county level) as well as for other Baltic countries (Katus 1991a, 1994). The Princeton fertility indices have proved to be extremely useful in presenting the fertility development and particularly comparisons during the transitional stage. They also constitute the main database for the short overview of the transitional stage in the current paper.

The earliest convenient datum for the comparison of fertility indices between the five coun- 
tries is the beginning of the $1880 \mathrm{~s}$. The obvious reason is the availability of data from the first census covering the Baltic guberniyas carried out in 1881. This census also supported the solid database for calculating the Princeton indices. The corresponding data for Finland and Sweden as well as for other European countries is taken directly from the Princeton project, for the closest year available to the census referred to in the Baltic area. The comparison is carried out in regard to the average Baltoscandia level and the countries of this region are plotted in a separate group before the others above the graph. The average for Baltoscandia should be regarded as a very rough estimation to serve as a kind of zero-point of relative measurement. The comparison of the overall fertility index is complemented by the index of marital fertility, which permits accounting for different marriage behaviors, particularly between the countries with and without the European marriage pattern. The results of the fertility comparison around 1880 are presented in Figure 1.

Figure 1. Overall and marital fertility indices: European countries compared to the Baltoscandian level, 1880 s.

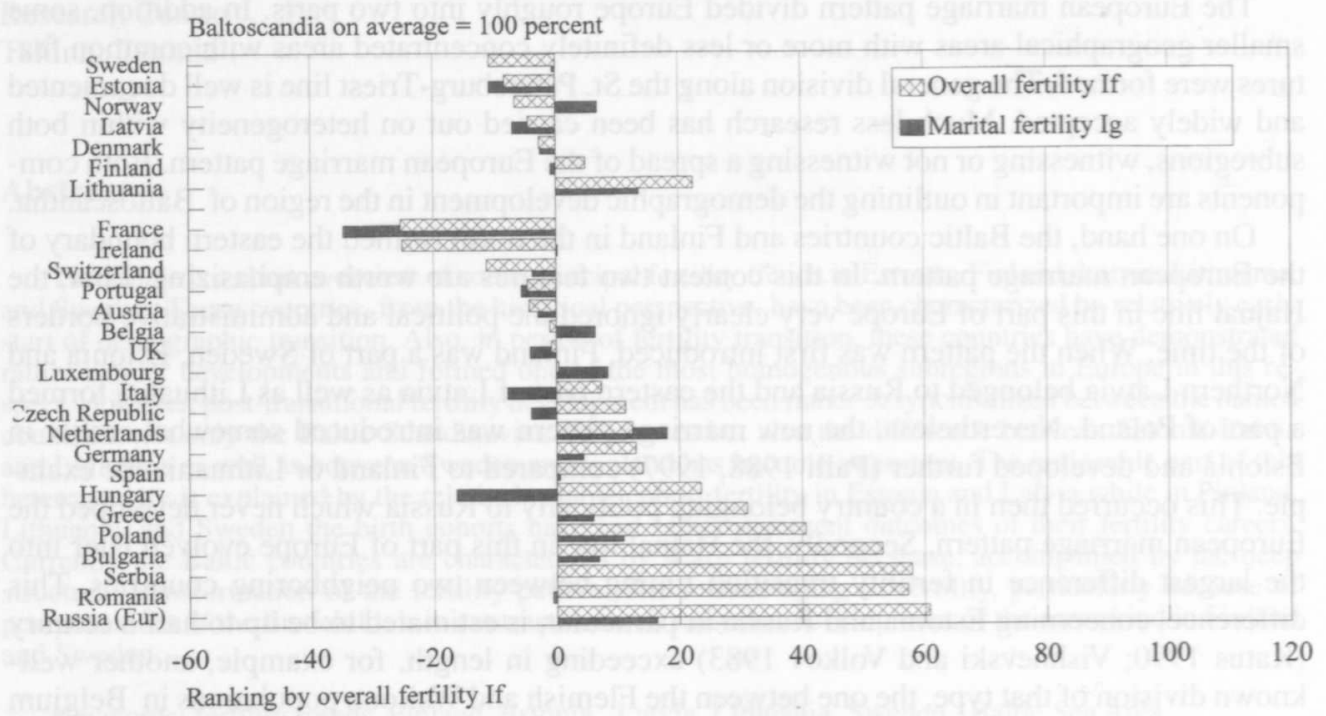

Figure 2. Overall and marital fertility indices: European countries compared to the Baltoscandian level, 1930s.

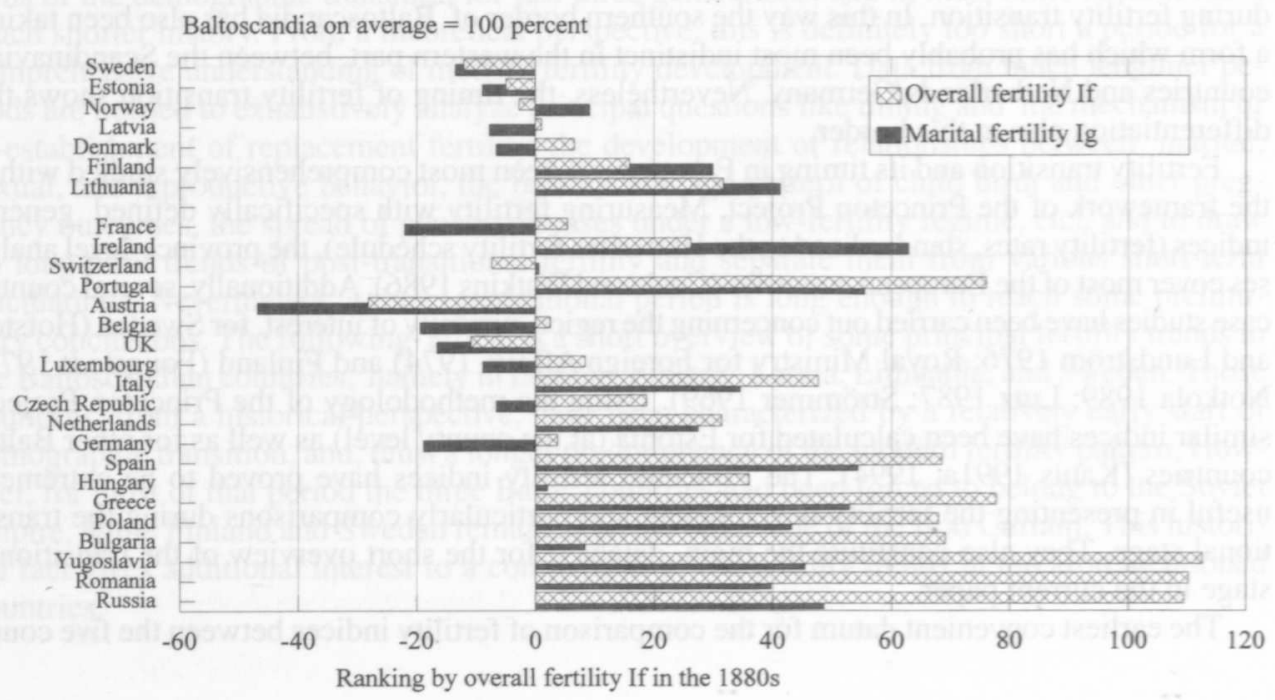


It is rather obvious that Baltoscandia is forming a relatively homogeneous region as to the fertility levels in the $1880 \mathrm{~s}$. With the exception of Lithuania all remaining countries exhibit a narrow range of \pm 10 percent or even closer. The overall fertility index in Lithuania is higher by ca 20 percent. The same index is also somewhat higher than average in Finland. On the other hand, Sweden and Estonia represent the countries with the lowest levels in this area, leaving Latvia, Norway, and Denmark in the middle position. Marital fertility adds some interesting details in Baltoscandia. In Sweden and particularly in Norway, the European marriage pattern was stronger and the relative level of overall fertility was noticeably lower than marital fertility. Conversely, Estonia, Latvia, and Finland represent the opposite relationship. Measuring by marital fertility, one can find the lowest levels of Baltoscandian fertility particularly in Estonia and Latvia at that time, and the highest in Norway - keeping Lithuania out of the comparison. However, the differences continue to remain rather small in the region, except in the case of Lithuania, which did not match Baltoscandia in terms of fertility development very well.

As to other European countries, there were only two with clearly lower overall fertility compared to Baltoscandia, namely France and Ireland. France is the well-known case of the first country in the world to begin the fertility transition, and Ireland's position is explained by extremely low marriage rates. Another group of countries, Switzerland, Portugal, Austria, Belgium, the UK, Italy, the Czech Republic, and some others, disclose more or less similar levels of overall fertility compared to Baltoscandia in the 1880 s. Some of those mentioned, for example, Portugal and Italy, happened to belong to the group because of their fertility levels at the time but clearly not for their subsequent fertility trends. Some others like Switzerland, Belgium, or the UK also demonstrate a similar fertility trend during the following decades and should be also considered among the countries of pioneering fertility decline. However, from a geographical point of view, they do not form a distinct subarea in Europe, despite the fact that they are all situated in the western and/or central part of Europe in more general terms. In other words, within the European territory west of the Hajnal line, Baltoscandia represents the most homogeneous subregion, particularly if one leaves Lithuania and (to a lesser extent) Finland aside. Moreover, the countries referred to are not the first ones to undergo the fertility decline, emphasizing their similarity even more.

A similar comparison of overall and marital fertility indices is carried out for the 1930s, when the fertility transition was coming to an end and underreplacement fertility had already been reached by the forerunners of European demographic development (Figure 2). The order of countries is kept the same as in previous comparison to make the changes more easy to follow. Already at first glance it becomes obvious that the magnitude of differences in fertility levels in Europe has widened a lot, roughly speaking they have doubled in size. Additionally, in many cases the ranking of the countries according to the overall fertility index has changed. In regard to Baltoscandia, the differences have also increased, but to a lesser extent. Moreover, the ranking of all countries in the region by the level of overall fertility has remained the same, meaning that development during the previous five decades was more or less simultaneous. Finland and particularly Lithuania are continuously characterized by a higher overall fertility. At the same time the difference compared to other countries in the region could have been much deeper if not the quickly progressing European marriage pattern had not served as an additional factor for reducing overall fertility. At that time Finland and Lithuania, together with Ireland, were almost unique in having a relatively higher marital fertility index compared to overall fertility. This was not the case for Finland and Lithuania during the 1880 s, which signifies a very intensive development of the European type of marriage in these countries, and catching up, literally speaking, with others in Baltoscandia. Lithuania and Finland seem to be two marginal countries, experiencing late but rapid development of the new marital type as a factor of decreasing fertility. In general, the homogeneity of Baltoscandia as a subregion has developed further.

The fertility development in countries like Switzerland and the UK seems to have been rather similar to that in Baltoscandia. In Belgium, Germany, Austria, the Czech Republic, and some other countries the overall fertility levels are also comparable but the development (and timing) happened to differ substantially from the typical trends in Baltoscandia. Concerning the South and East European countries the differences have sharply increased twofold or even 
more. In other words, the boundary between Baltoscandia and its eastern neighbor Russia has become even more distinct than earlier, and the incoherence between Estonia and Russia proves to be the highest among any two close neighbors in Europe at that time. Obviously the expansion of the discrepancy between Baltoscandia as a subregion in general and Russia on the other hand had been noticeably supported by the fertility development in Finland and Lithuania. Development during these fifty years in these countries had quickly removed them further from Russia and closer to the situation prevailing in other Baltoscandian countries. The same is true if one compares Lithuania and Poland, which makes the division between the Baltic region and Central Europe more evident. Like half a century earlier, the boundary between the Scandinavian countries and Western Europe is continuously less distinct, however, the dissimilar fertility trends in Netherlands and Germany, not to mention France, supply no ground for distinguishing a larger geographical region in the western part of Europe with more or less close similarities on this side of the Hajnal line. Actually, Baltoscandia as a subregion has become more homogeneous and distinct from other countries of Western and Central Europe at that time.

Figure 3 outlines the differences in fertility levels between the five countries being considered and their eastern neighbor more specifically. In addition to Russia as a whole three adjacent Russian guberniyas/oblasts, namely St. Petersburg, Pskoff, and Novgorod, are included separately in the comparison. Overall fertility indices are compared for both of the analyzed time points, in the $1880 \mathrm{~s}$ and the 1930 s. The Russian regions neighboring the Baltic countries, except St. Petersburg, demonstrate very high fertility levels common to Russia on the average. In the 1880 s the overall fertility was somewhat lower in Novgorod and Pskoff guberniyas compared to Russia as a whole, however, in the 1930 s the fertility level in these oblasts was even higher than the country average. The difference exceeded 100 percent or was two times greater. It is also noticeable that the differences in fertility between Baltoscandia and Russia had grown rapidly by the 1930 s. This demonstrates a considerable time lag in demographic development between the regions named. This time lag could be estimated at up to half of a century compared with Sweden, Estonia, and Latvia. The same trends were also characteristic of a comparison with Poland: the period under consideration was characterized by a noticeable difference and a widening gap. Fertility transition in Poland occurred somewhat earlier compared to West-Russian regions, nevertheless remaining closer to Russia than Baltoscandia. The differences between Lithuania and Poland had also grown by the 1930 s.

Figure 3. Overall fertility indices: Baltoscandia and neighbors, 1880s and 1930s.

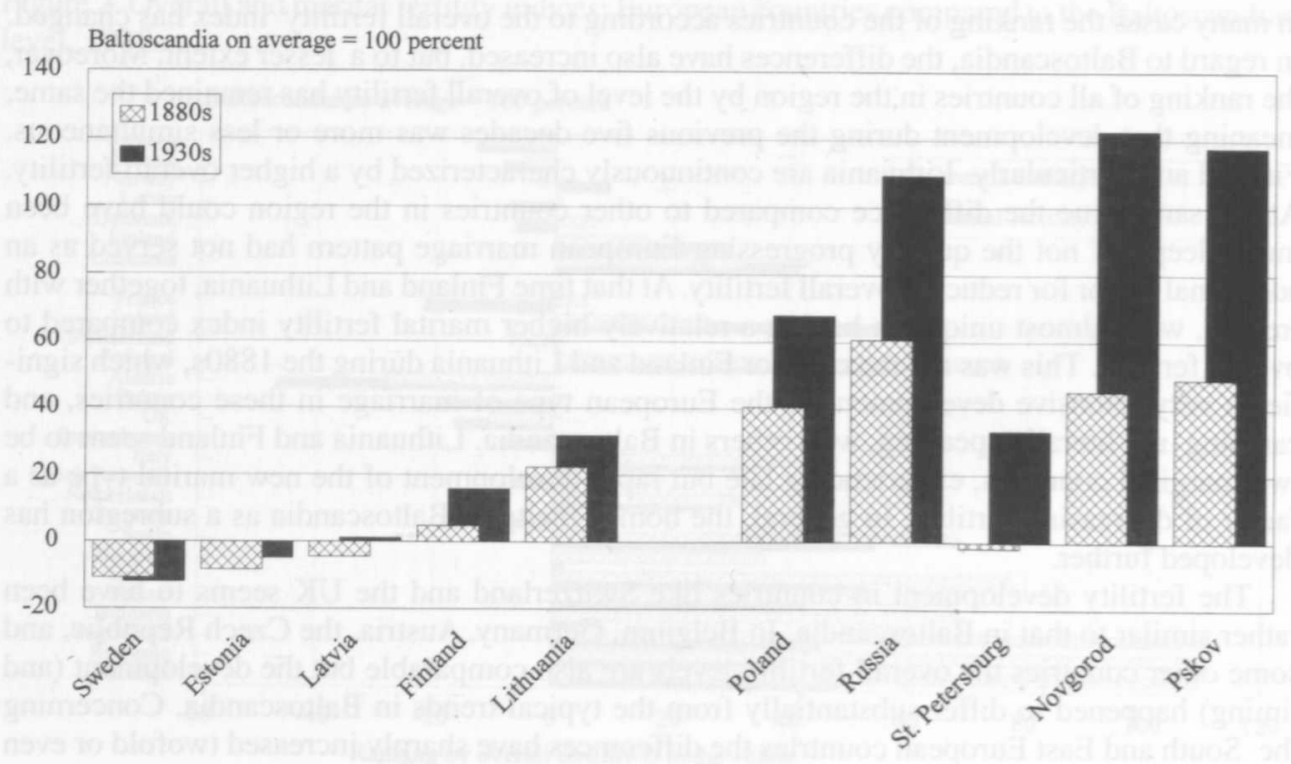


St. Petersburg guberniya seems to be a special case. In this region the fertility transition began rather early, and the levels of fertility indices were comparable to Baltoscandia in the 1880s. Hajnal (1965) also noticed the same common features in marital patterns and drew his well-known line from St. Petersburg, and not from Murmansk or Narva, for example. According to available data, St. Petersburg was the only Russian guberniya demographically separated from all the others. One can easily conclude that the low fertility in the St. Petersburg region developed under the impact of the very high urbanization prevailing in the area. St. Petersburg being the capital city of the Russian empire as well as the selectivity of the city population could be a real hypothesis for explaining the demographically unique situation of St. Petersburg guberniya. However, the fertility situation in St. Petersburg/Leningrad oblast changed later on and the difference between the region and Baltoscandia had grown sharply by the $1930 \mathrm{~s}$. Demographic development seems to have stopped there for a couple of decades at least, or even taken another direction.

Another possible explanation of specific fertility development in St. Petersburg/Leningrad oblast is the mass population displacement in the region during the last 100-120 years. Historically Ingria was populated by Finnish-speaking nations: Votes, Ingrians, Finns, and Estonians (Kurs 1990). Only after the conquest of Ingria by Peter the Great, and the building of the new Russian capital in the middle of that country, was the mass migration inflow of Russians initiated. Nevertheless, the large Finnish-speaking population also remained in the region. Population displacement alongside with assimilation - particularly of the orthodox members of the Finnish population - gained strength in the last decades of the 19th century (Engman 1993). The process culminated in the 1920-1940s when mass deportations of non-Slavic ethnicities took place from Leningrad oblast, and was nearly completed during World War II. Thus, in the perspective of the last century, the principal population discontinuity is clearly evident in Ingria, or Leningrad oblast in the modern sense, and only a few comparable cases of similar development can be found in the Königsberg/Kaliningrad area. This population discontinuity could, and certainly should, partially explain the sharp increase of fertility differences between Baltoscandia and this closely neighboring Russian region in the 1920-1930s.

One of the possibilities for determining the cessation of the fertility transition period is to look for when underreplacement fertility was reached for the first time. This simple measure is easy to apply and gives rather adequately a rough idea about the time of completion of the previous long period of continuous fertility decline. When fertility has already dropped as low as underreplacement, the declining trend cannot keep on in this direction much longer, referring, inter alia, to the finalization of the transition era. Relatively speaking, one could start to count, in quantitative terms, the beginning of post-transitional or modern fertility development from the same time period. Figure 4 tries to capture the time point when underreplacement fertility was reached for the first time. The simple line at 2.15 TFR refers to the replacement level which, of course, is an oversimplification. In reality the replacement level depends on mortality, particularly on infant mortality, and therefore also decreases during the demographic transition. However, for the current task, the fixed replacement fertility is sufficient enough to estimate the final stage of fertility transition in the five Baltoscandian countries. As previously, the forerunners in this subregion in the timing of when underreplacement fertility was reached continued to be Sweden, Estonia, and Latvia. The Swedish fertility decline was relatively sharp in the beginning of the century and the underreplacement level was reached in the first half of the 1920 s, followed by Estonia a couple of years later. In the early 1930s Latvia also joined the group. Finland and Lithuania did not reach this level until the late 1960s and 1970s, correspondingly. In the case of Finland the declining trend had a definite time lag compared to Sweden, Estonia, and Latvia, but it was rather sharp, and the net reproduction rate actually fell under 1 for a short period in the second half of the 1930s. The tremendous baby boom extended the onset of continuous underreplacement fertility 30 years into the future. In the case of Lithuania the time lag has been much more expressed and a more or less gradual fertility decline has continued throughout the 1930 s to the 1960 s. With the finalization of the fertility transition, Lithuania should be regarded as a marginal country between Baltoscandia and Central Europe. However, the fertility development in neighboring Belorussia and Poland, once again lend ground for the inclusion of Lithuania in Baltoscandia. 
Figure 4. Total fertility rate: Baltic countries, Finland, and Sweden 1915-1955.

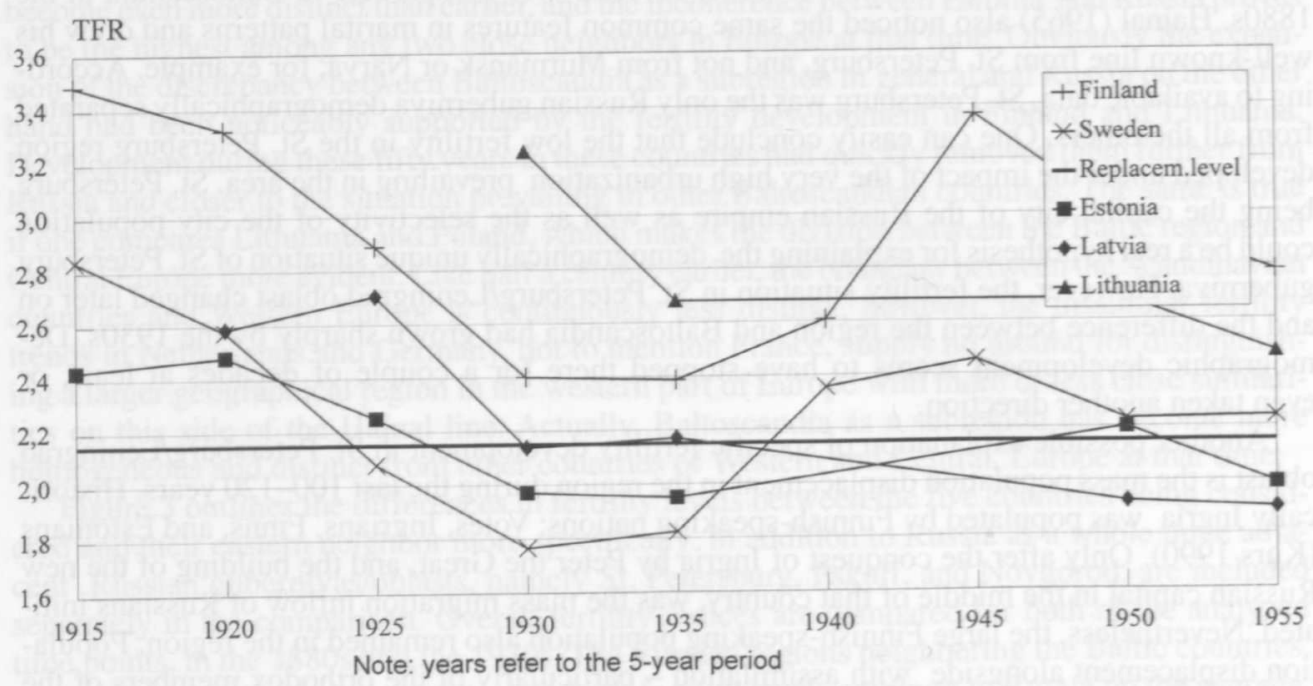

Summarizing the period of fertility transition, the Baltoscandian countries have demonstrated rather similar developments and formed one of the most homogeneous subregions in Europe in this respect. Two countries showing the largest differences within the region, Finland and Lithuania, have both been subjects of the current article, and their divergence from the subregional average has been proved relatively small compared to the European differences during the whole period of fertility transition.

\section{Post-transitional fertility divergence}

The timing of the finalization of fertility transition and the beginning of the post-transitional period in fertility development has not been strictly simultaneous among Baltoscandian countries, as discussed in the previous section. Nevertheless, most of the countries of the region, with the single obvious exception of Lithuania, have experienced underreplacement levels already before World War II. Leaving the period of war aside, conventionally, the stage of posttransitional fertility in Baltoscandia could be counted from the second part of the 1940s or the early $1950 \mathrm{~s}$. When analyzing the following fertility development, two important characteristics should be considered. First, post-transitional fertility should be regarded as a new phenomenon. There is not necessarily a causal link between transitional and post-transitional fertility developments. In other words, the more or less universal process of fertility transition is not necessarily followed by some kind of universal post-transitional development, varying from country to country mostly by timing. Second, at the end of World War II the Baltic countries found themselves occupied by Russia/the Soviet Union. Once again Baltoscandia was politically divided, but this time major emphasis was put on creating an ideological, economic, and social border stronger than ever before. In the Baltic countries the extremely violent sovietization of the society and the establishment of the Iron Curtain have undoubtedly had a serious impact on social development, population processes included. On the other hand, demographic development is among the most inert social processes, responding relatively weakly to any influence. In this respect Baltoscandia has become a very interesting laboratory for testing the potential magnitude of possible influences on fertility development, which is obviously a much more complex task from a methodological point of view than quantification of all possible similarities and differences between the Scandinavian and Baltic regions within Baltoscandia. 
General fertility development in the five Baltoscandian countries of interest are compared using the period total fertility rate (Figure 5). Fertility levels as well as trends demonstrate a rather heterogeneous situation. Without prior knowledge of a long-term noticeable homogeneity of fertility trends and even timing during the transitional period between these countries, the data on the graph could not support the hypothesis to look, among other things, for the principal similarities in fertility development. Such a situation is also a good example for emphasizing the need for a long-term outlook on any demographic process, if general features are under discussion. However, fertility has been really heterogeneous during the postwar period and naturally demands some explanation.

Among all the differences in fertility levels and trends, two important features need to be underlined. First, Estonia and Latvia witnessed no baby boom after World War II. This is partly true also for Lithuania but this country did not experience underreplacement fertility before the World War II either. The absence of a postwar baby boom in Estonia and Latvia has obviously been the exceptional feature of the fertility trend among the forerunners of the fertility transition. All countries having experienced the underreplacement fertility in the $1920 \mathrm{~s}-1930 \mathrm{~s}$, except Estonia and Latvia, have also faced the postwar baby boom (see also Daguet 1996). That fertility increase has not been a short-term phenomenon but has lasted up to the mid-1960s (Festy 1984; Sardon and Calot 1997). Neither has it been a minor trend in increase: all the lowfertility countries reached the replacement fertility during the baby boom. Estonian and Latvian fertility, on the contrary, remained systematically below the said level for an additional 20-25year period. At that time these countries had constantly the lowest fertility in Europe and correspondingly in the world.

The second important feature of the heterogeneous fertility trend in Baltoscandia is no less exciting. As was already discussed in some previous papers, the end of the 1960s marks the introduction of a new trend in Estonian, and to a slightly lesser extent, in Latvian period fertility (Katus 1991a, 1991b). This same period has been an era of rather important demographic changes everywhere in Europe, particularly for the baby boom countries, where fertility demonstrated the beginning of a sharp decrease at that time. In the current study Sweden and Finland represent this course of development. Contrary to this general European trend, Estonian and Latvian period fertility surprisingly began to rise. The increase was rather substantial in Estonia: more than 17 percent in the total period fertility rate in four years (1971 compared to 1967). Moreover, the increase also proved to be a long-term change, and period fertility in Estonia remained higher compared to the previous forty-year interval of 1928-1968 up to the end of the 1980s.

Figure 5. Period total fertility rate: Baltic countries, Finland, and Sweden 1950-1990.

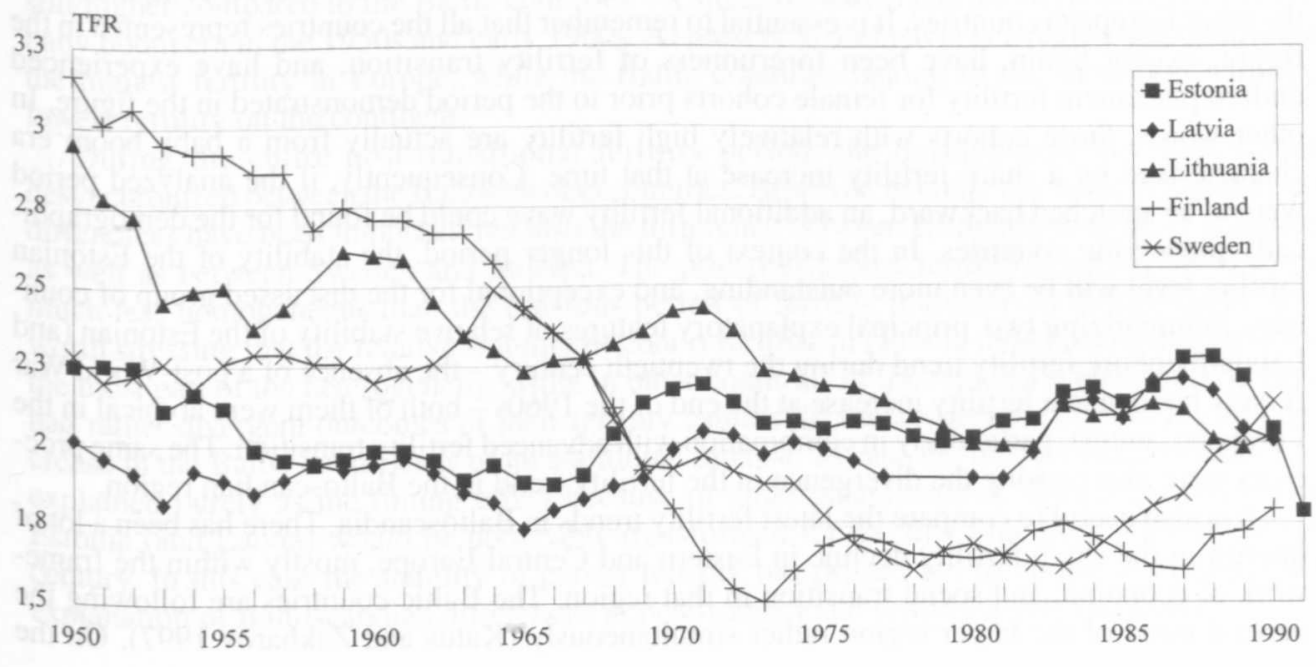


This increase in period fertility in the late 1960s has not received appropriate attention, partially because it was regarded exceptionally as the result of a timing effect. Obviously, the period indicators have really been influenced by the accelerated rejuvenation of fertility, briefly discussed in the current paper. Nevertheless, the data on cohort fertility confirms that the increase of period indicators has a definite impact on completed fertility, as well. This increase seems to be of particular importance because completed fertility of the female cohorts 19501959 rose close to replacement, particularly in the case of Estonia, after $40-45$ years of lower fertility. In other words, the discussed fertility increase in Estonia and Latvia left no country with early underreplacement fertility continuously below that level. Sooner or later all of them have experienced growth. It provides grounds for one possible hypothesis explaining the posttransitional fertility divergence between Scandinavia and the Baltics: in Estonia and Latvia the baby boom was just delayed, because of repressions, the sovietization of the society, etc. However, the phenomenon as such was principally the same as in other countries. In this case the divergent trend in the late 1960s in Estonia and Latvia on the one hand, and Finland and Sweden (as well as most of the North and Western European countries), on the other, was simply a coincidence. A significant deficiency of such a hypothesis is the absence of the correspondence of fertility increase with any known major shifts in the Soviet society. Sovietization, for example, became much more liberal after Stalin's death, more than a decade prior to the fertility increase.

The divergence of the post-transitional fertility trend is obvious already in the period measures. Nevertheless, it is also worth comparing cohort data on completed fertility in order to remove various conjunctional fluctuations, and particularly the effect of fertility rejuvenation, which was common to most of the countries which experienced the European type of marriage. Figure 6 compares cohort total fertility rates for Baltoscandian and some other European countries. Data for this purpose is derived, if available, from Sardon's article and the Council of Europe's demographic yearbook (Council of Europe 1992-1997; Sardon 1990). In the case of the Baltic countries, national reports for the European FFS project have been used in addition (EKDK 1995; Stankuniene and Baublyte 1996; Zvidrins 1996). For presentation, annual cohort fertility rates are aggregated into five-year cohorts. It should be noted that survey data on completed fertility in Lithuania and to a lesser extent in Latvia does not correspond to period data from vital statistics, but the difference is not explained in the cited publications. This diminishes the comparability of those countries as well as availability of data series for a shorter time interval.

The cohort indicators present more precisely the fact that the fluctuation of the Estonian (and presumably Latvian) cohort fertility within the interval of $1.9-2.1$ in the total rate seems very stable when considering the rather large-scale changes in other European countries. The fertility level has been the lowest for the older female birth cohorts under observation (cohorts of 1924-1943), but almost the highest for the younger cohorts of 1949-1963, if compared with the other European countries. It is essential to remember that all the countries represented in the figure, except Spain, have been forerunners of fertility transition, and have experienced underreplacement fertility for female cohorts prior to the period demonstrated in the figure. In other words, those cohorts with relatively high fertility are actually from a baby boom era characterized by a sharp fertility increase at that time. Consequently, if the analyzed period were to be stretched backward, an additional fertility wave could be found for the demographically pioneering countries. In the context of this longer period, the stability of the Estonian fertility level will be even more outstanding, and exceptional for the discussed group of countries. Summarizing two principal explanatory features of relative stability of the Estonian (and Latvian) cohort fertility trend during the twentieth century - the absence of a post-World War II baby boom and a fertility increase at the end of the 1960 s - both of them were atypical in the European context, particularly in combination with advanced fertility transition. The same processes were also causing the divergence in the fertility trend in the Baltoscandian region.

It is also useful to compare the latest fertility trends in Baltoscandia. There has been a lot of interest in the sharp fertility decline in Eastern and Central Europe, mostly within the framework of economic and social transition in that region. The Baltic countries are following the general trend of the larger region rather simultaneously (Katus and Zakharov 1997). On the 
Figure 6. Cohort total fertility rate: birth cohorts 1924-1963.

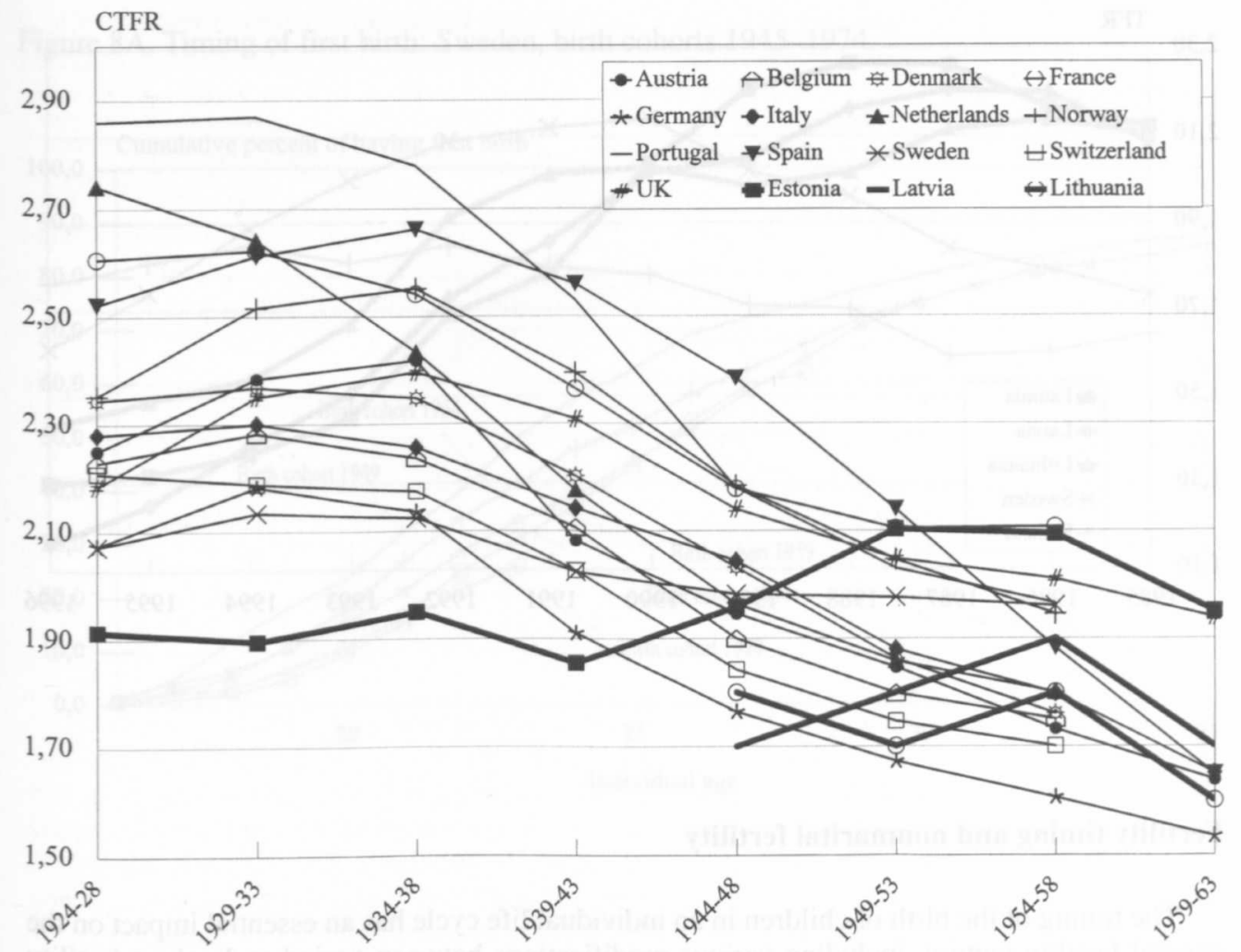

Note: The survey data of Latvia and Lithuania does not correspond to the period data of vital statistics.

other hand a noticeable fertility increase in Sweden up to the replacement level has also been under great interest, not only locally (Calot and Sardon 1997). Here the Baltoscandian countries are compared to each other using the period total fertility rate (Figure 7). Once again the diverse trend in fertility should be stressed. To the background of a sharp and simultaneous fertility decline in all three Baltic countries, Finland and particularly Sweden are demonstrating increase. In spite of the fact that Swedish fertility has fallen considerably by now, its level is still higher compared to the Baltic countries - a situation which has not been evident after the baby boom era in the 1950 s and early 1960 s. At present Scandinavia is a region demonstrating the highest fertility in Europe, while the Baltic countries belong to the subregion with the lowest fertility on the continent.

During the entire post-transitional fertility period, the development has been rather desynchronized between the Baltoscandian countries. However, not only the Baltic-Scandinavian differences have been important but also the difference between Estonia/Latvia and Lithuania, as well as between Sweden and Finland. The post-transitional fertility era has proved to be much less homogeneous than the previous period of fertility transition in Baltoscandia. It is worth stressing that the relative stability of cohort fertility in Estonia (and Latvia) accounts for the most part of the heterogeneity, while in other countries of the region the birth cohorts have had rather divergent outcomes of their fertility careers. In this respect the current fertility decrease in the Baltic countries is of an additional interest. In case the fertility decline cannot be explained purely as the timing effect because of child postponement, the cohort fertility in Estonia (and Latvia) would be noticeably transformed for the first time during the twentieth century. In this case the stability of cohort fertility has proved not to be the most important explanation of Baltoscandian differences in post-transitional fertility levels and trends. 
Figure 7. Total fertility rate: Baltic countries, Finland, and Sweden 1985-1996.

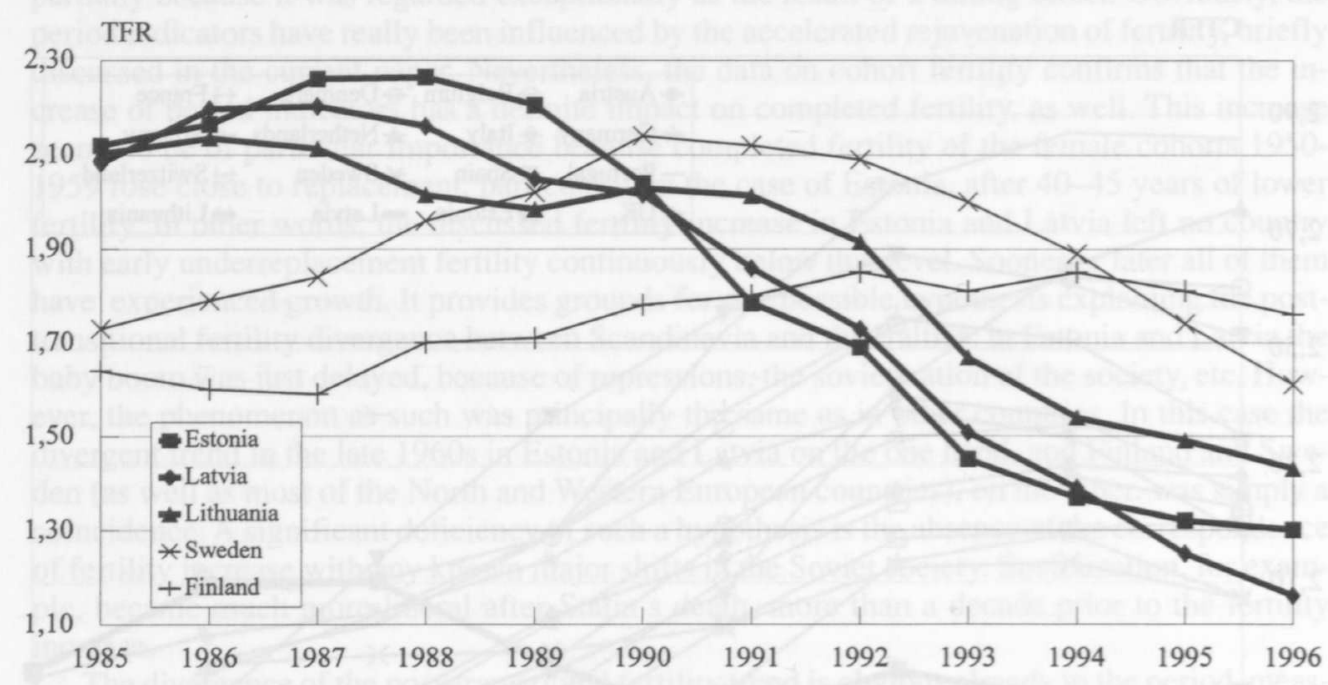

\section{Fertility timing and nonmarital fertility}

The timing of the birth of children in an individual life cycle has an essential impact on the general fertility pattern, including various modifications between period and cohort fertility measures. In some cases timing has proved to be even more important than the level, when following similarities and dissimilarities of fertility development in the longer run. The changes in the development of marital behavior approximately two and a half centuries ago described by Hajnal should be remembered once again, when dealing with the beginning of post-transitional fertility. The majority, if not all countries characterized by the European type of marriage and early fertility transition, have also experienced the fertility rejuvenation in the middle of this century, particularly during the early years of the baby boom (Festy 1984). However, the significance and duration of the process differed remarkably in particular countries. Later on the rejuvenation trend changed to fertility aging but, again, the timing of this transformation showed a variation of more than two decades.

Fertility rejuvenation and aging could be followed by different indicators. In the current article the cumulative percentage of having the first baby is used, and presented for different female birth cohorts. Availability of such data is not very common even for the individual countries, and much more rare for a comparative analysis. In the present case the European FFS is serving as a database (UN and ECE 1993). All of the five countries under consideration were covered by FFS and standard results at least, or more sophisticated analyses, are available by now (Granström 1997; EKDK 1995; Nikander 1992; Stankuniene and Baublite 1996; Zvidrins 1996). For the Baltic countries, the survey was the first of this kind at the nation-wide level and, correspondingly, the cohort data on timing of fertility are rather novel. The cumulative percentage of having the first child is presented for each country by female 5-year birth cohorts available from the national studies. These birth cohorts do not exactly coincide from one country to another. In the case of Estonia a wider range of cohorts is covered, starting already from the birth cohort of 1924-1928. For Sweden the birth cohorts are not constructed as an average of five successive 1-year cohorts, but presented directly by oversampled single-year birth cohorts. For the current purpose of estimating the general rejuvenation/aging pattern of fertility identi- 
cal birth cohorts are not necessary. The timing of cohort fertility (delivery of the first child) is presented for each country on a separate but similarly designed graph (Figure 8A-E).

Figure 8A. Timing of first birth: Sweden, birth cohorts 1945-1974.

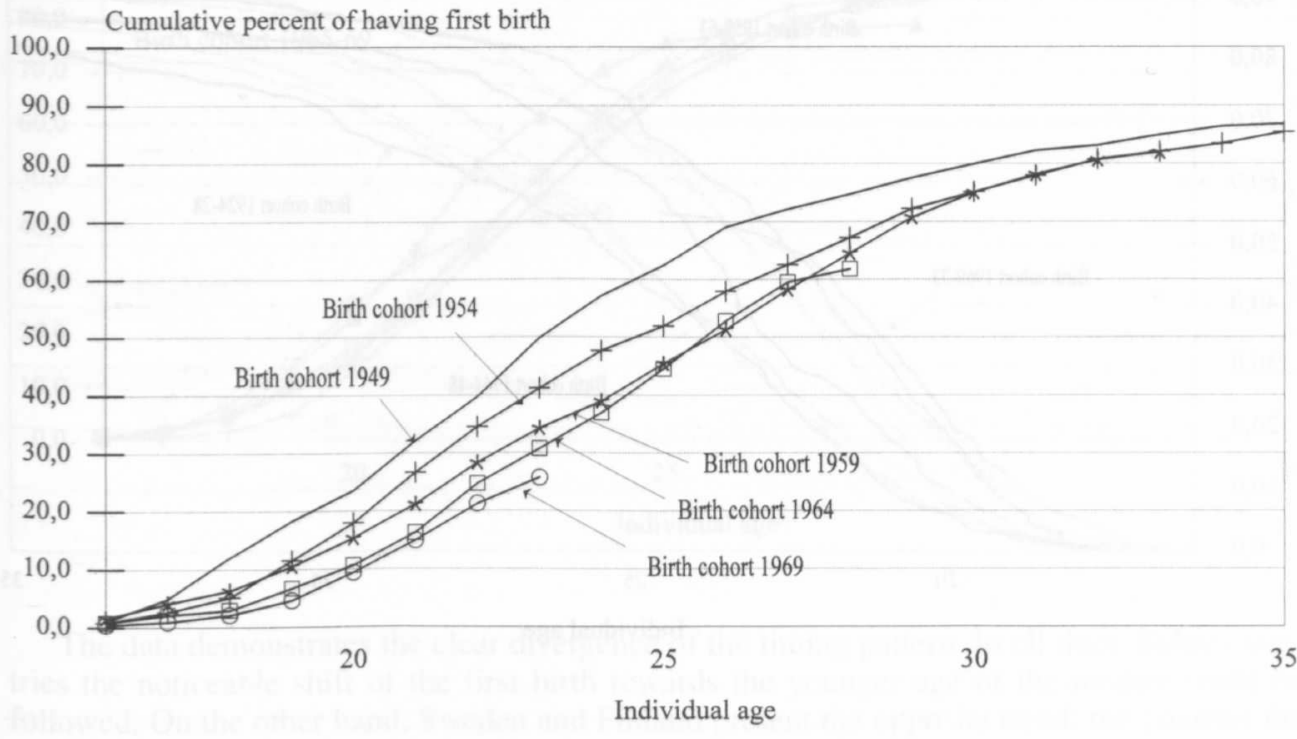

Fiugre 8B. Timing of first birth: Finland, birth cohorts 1945-1974.

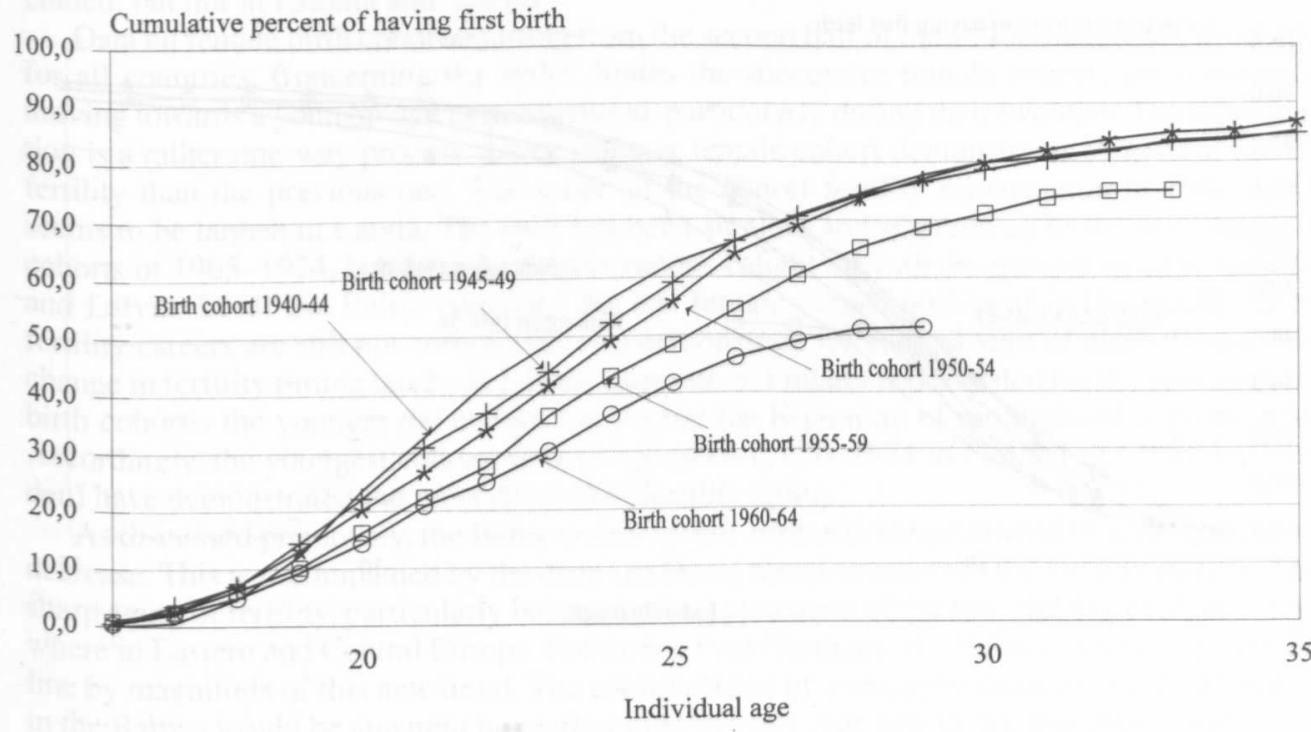


Figure 8C. Timing of firts birth: Estonia, birth cohorts 1924-1973.

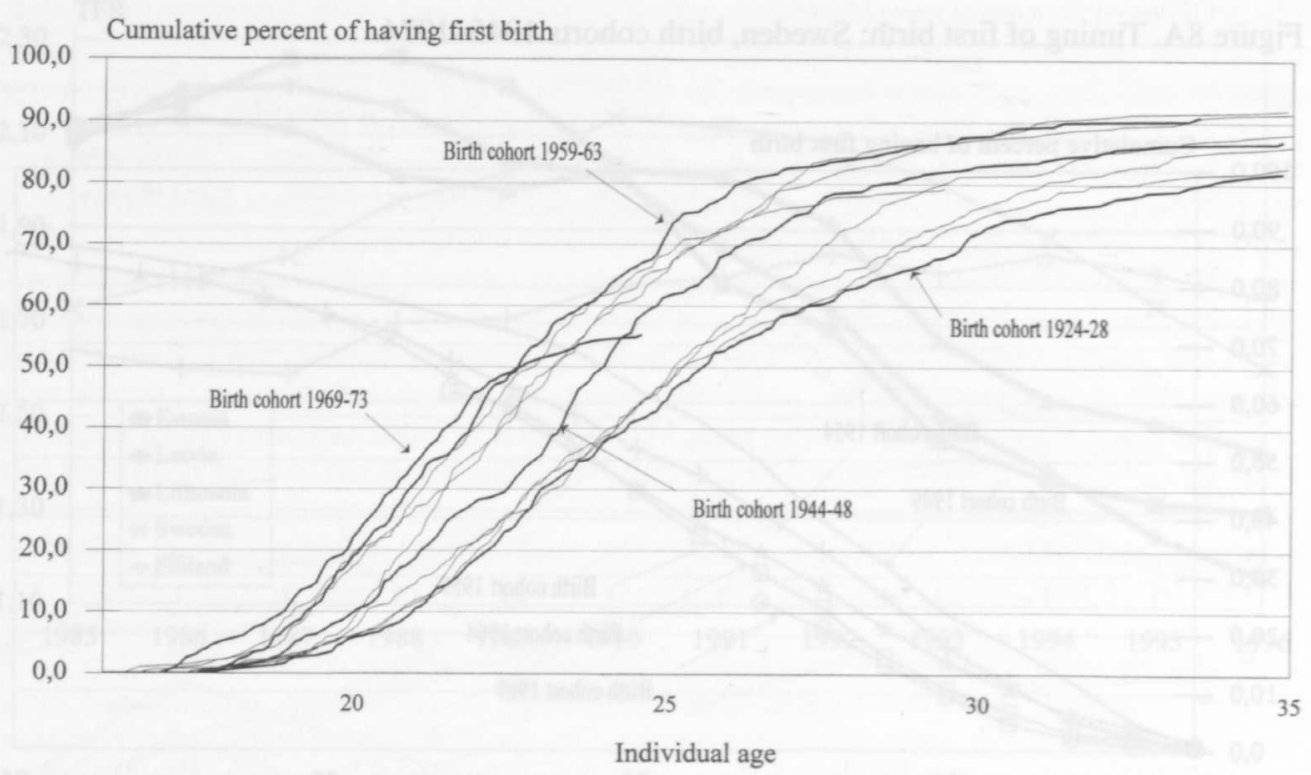

Figure 8D. Timing of first birth: Latvia, birth cohorts 1945-1974.

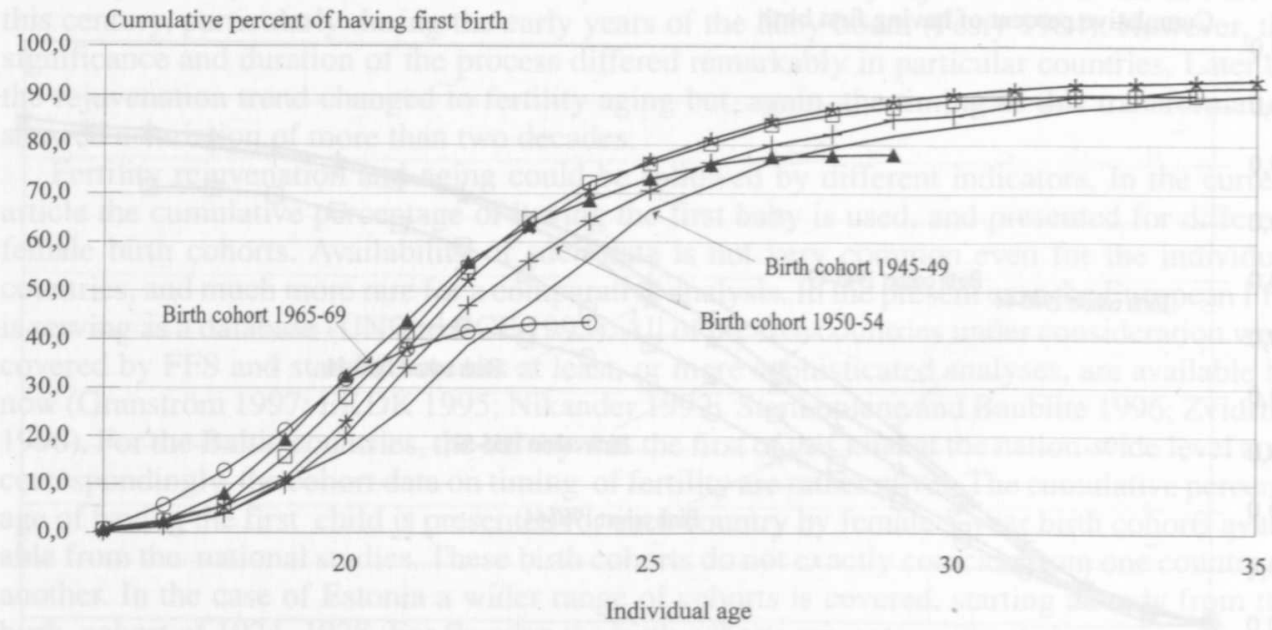


Figure 8E. Timing of first birth: Lithuania, birth cohorts 1945-1974.

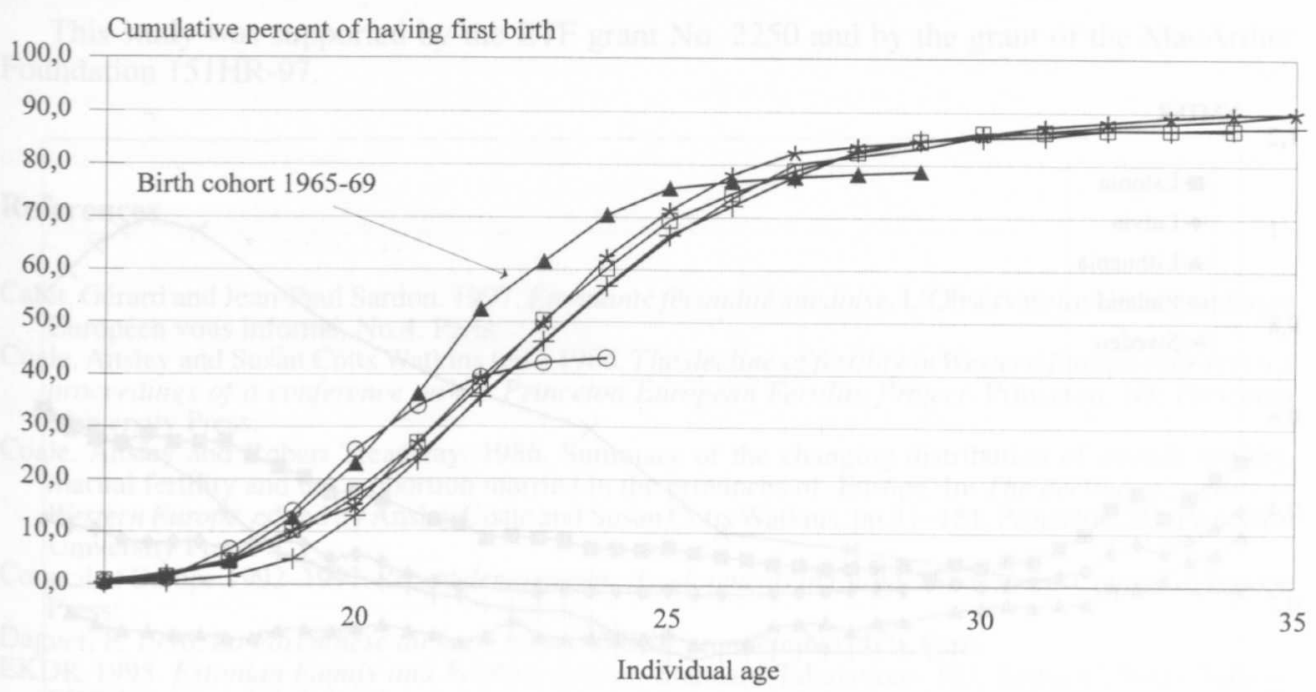

The data demonstrates the clear divergence of the timing pattern. In all three Baltic countries the noticeable shift of the first birth towards the younger age of the mother could be followed. On the other hand, Sweden and Finland present the opposite trend: the younger the female cohort, the older the mother's age at first delivery. The divergence would be much less expressed, if data for the older female cohorts, particularly for Finland and Sweden, could be added as well. In such case the dynamics expressed by Estonian (and Latvian) older cohorts would be rather similar to the corresponding birth cohorts in Scandinavia. The emergence of a baby boom has been accompanied by fertility rejuvenation and a decrease of completed childlessness everywhere in Europe, very much like the dynamics of the Estonian cohorts from 1924-28 to 1944-1948. In other words, concerning the prewar female birth cohorts homogeneity has prevailed in the dynamics of the fertility timing pattern in Baltoscandia, with the assumed exception of Lithuania. As discussed previously, however, a similar rejuvenation has resulted in a substantial fertility increase in most of the countries, Finland and Sweden included, but not in Estonia and Latvia.

Data on female birth cohorts starting from the second half of the 1940s are already available for all countries. Concerning the Baltic States the successive female cohorts are constantly moving towards a younger age of motherhood, particularly during their twenties. The rejuvenation is a rather one-way process: every younger female cohort demonstrates somewhat earlier fertility than the previous one. The scope of the cohort fertility rejuvenation in 1945-1974 seems to be largest in Latvia. The shift has been smallest in Lithuania up to the two youngest cohorts of 1965-1974, but these latter generations caught up with the general trend in Estonia and Latvia. In all the Baltic countries the last female cohort presented in the graphs (their fertility careers are still not completed) also demonstrate the earliest start of motherhood. The change in fertility timing has been just the opposite in Finland and Sweden for the same female birth cohorts: the younger the cohort, the further the beginning of motherhood is postponed. Accordingly, the youngest cohorts in both countries (1970-1974 in Finland and 1969 in Sweden) have demonstrated the most developed fertility aging.

As discussed previously, the Baltic countries are currently characterized by a sharp fertility decrease. This is accompanied by the deep structural transformation of the fertility pattern. The sharp aging of fertility, particularly because of postponement of the first child is evident everywhere in Eastern and Central Europe. Following East Germany, the Baltic countries are next in line by magnitude of this new trend. The cohort effects of a changing timing pattern of fertility in the Baltics would be apparent not earlier than in a ten-year period. By that time it would not 
Figure 9. Nonmarital total fertility: Baltic countries, Finland, and Sweden 1950-1996.

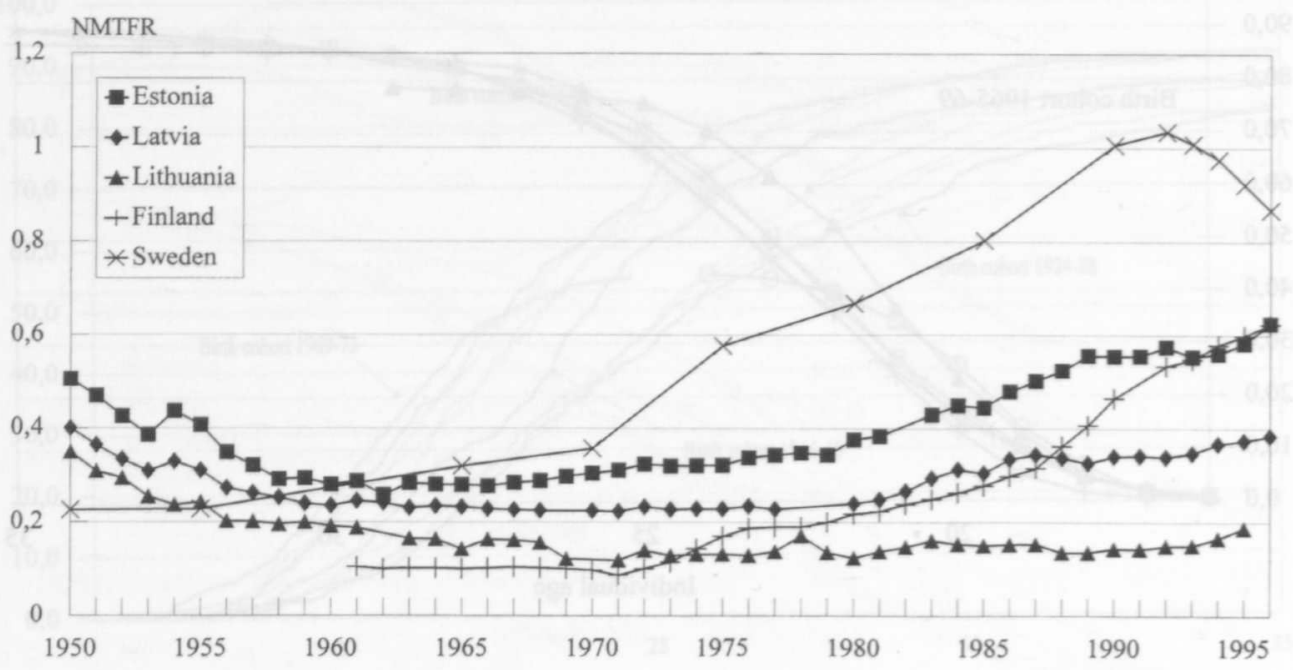

be surprising if the level of fertility aging, similar to that experienced in Sweden and Finland during the last 30 years, is already reached, and in a considerably shorter period. Nevertheless, whatever the future trends, the post-transitional fertility during the last 50 years should be regarded as divergent in Baltoscandia also concerning the timing pattern.

The general trend of fertility as well as its level and timing have demonstrated divergence in Baltoscandia after the relatively homogeneous period of fertility transition. During the latter period Finland and Lithuania were countries having somewhat larger differences compared to Estonia, Latvia, and Sweden. In the period of post-transitional fertility the borderline between subgroups within Baltoscandia tended to coincide with the borders marked by the Iron Curtain. This relationship, among others, is simply taken as a starting point in many demographic studies. In spite of the various possible directions of influence of different societal structures on fertility, the apparent relationship should not be prematurely taken as the causal one. Quite possibly, the observed differences are partly caused by an inherent divergent trend in the early phases of post-transitional fertility and half a century is just too short a period to draw conclusions. To give some basis for such a hypothesis and to demonstrate the similarities and dissimilarities of fertility development in Baltoscandia from another angle, one could turn to nonmarital fertility.

Nonmarital fertility in the Baltics and Finland during the postwar (World War II) period is compared in a previous paper (Katus 1993). One of the conclusions of that analysis could be summarized as follows: the nonmarital fertility trend and level seem to be rather independent from the overall fertility. If true, the nonmarital fertility is another important aspect among others discussed above in outlining the general fertility situation. In the current paper the process is presented by the nonmarital total fertility rate (Figure 9). Data are derived from the cited article, updated for the last two years, with Sweden. Nonmarital fertility demonstrates the simultaneous trend in most of the countries, except Lithuania. Sweden has had the highest level starting from the 1970 s, but the second position is continuously held by Estonia. Also the Latvian level has exceeded the Finnish one up to the middle of the 1980s. The Baltic countries mentioned had extremely divergent nonmarital fertility with a background typical in the USSR or in Eastern Europe, in general. No boundaries like the Iron Curtain could explain a diversity in nonmarital fertility such as that demonstrated by Estonia and Latvia throughout the whole postwar period. 


\section{Acknowledgements}

This study was supported by the ETF grant No. 2250 and by the grant of the MacArthur Foundation 151HR-97.

\section{References}

Calot, Gérard and Jean-Paul Sardon. 1997. Etonnante fécondité suédoise. L'Observatoire Démographique Européen vous informe, No.4. Paris.

Coale, Ansley and Susan Cotts Watkins (ed.) 1986. The decline of fertility in Western Europe : the revised proceedings of a conference on the Princeton European Fertility Project. Princeton, NJ: Princeton University Press.

Coale, Ansley and Robert Treadway. 1986. Summary of the changing distribution of overall fertility, marital fertility and the proportion married in the provinces of Europe. In: The decline of fertility in Western Europe, edited by Ansley Coale and Susan Cotts Watkins, pp.31-181. Princeton, NJ: Princeton University Press.

Council of Europe.1992-1997. Recent demographic developments in Europe. Strasbourg: Council of Europe Press.

Daguet, F. 1996. La Parenthése du baby boom. INSEE premiére No. 479. Paris.

EKDK 1995. Estonian Family and Fertility Survey. Standard Tabulations. RU, Series C, No.6. Tallinn: EKDK.

Engman, Max. 1993. St. Petersburg as a melting pot. Paper presented at the IX Visby Symposium for Historical Sciences. Visby.

Festy, Patrick. 1984. Fertility in Western countries (1870 to 1970). Population Studies Translation Series, No. 7. Bangkok: ESCAP, Population Division.

Fougstedt, Gunnar. 1977. Trends and factors of fertility in Finland. Commentationes Scientiarum Socialium, No. 7. Helsinki: Societas Scientiarum Fennica.

Granström, Frederik.1997. Fertility and family surveys in countries of the ECE region: standard country report: Sweden. Economic studies No. 10 b. New York and Geneva: United Nations.

Hajnal, John. 1965. European marriage patterns in perspective. In: Population in history: essays in historical demography, edited by D.V. Glass and D.E. Eversley, pp.101-43. Chicago, IL: Aldine Publishing Company.

Hofsten, Erland and Hans Lundström. 1976. Swedish population history: main trends from 1750 to 1970. Stockholm: National Central Bureau of Statistics.

Katus, Kalev. 1990. Demographic trends in Estonia throughout the centuries. Yearbook of Population Research in Finland 27:50-67.

Katus, Kalev. 1991a. Fertility trends and regional differences in Estonia. RU, Series B, No.12. Tallinn: EKDK.

Katus, Kalev. 1991b. Fertility transition and post-transitional fertility trend in Estonia. Estonian-Swedish Seminar on Demography. Viljandi.

Katus, Kalev. 1993. Trends in non-marital fertility in Baltic region. RU, Series B, No.21. Tallinn: EKDK.

Katus, Kalev. 1994. Fertility transition in Estonia, Latvia and Lithuania. In: Demographic trends and patterns in the Soviet Union before 1991, edited by W. Lutz, S. Scherbov, and A. Volkov, pp. 89-113. London: Routledge.

Katus, Kalev and Sergei Zakharov. 1997. Demographic adaptation to socioeconomic changes in the USSR successor states. Paper presented at the IUSSP 23rd General Population Conference. Beijing.

Kurs, Ott. 1990. Ingeri põliselanike saatus. Akadeemia, No.7, lk.1484-1520.

Lesthaeghe, Ron J. 1977. The decline of Belgian fertility, 1800-1970. Princeton: Princeton University Press.

Lutz, Wolfgang. 1987. Finnish Fertility since 1722: lessons from an extended decline. Publications of the Population Research Institute, Series D, No. 18. Helsinki: The Population Research Institute and Laxenburg: International Institute for Applied Systems Analysis.

Nikander, Timo. 1992. Naisen elämänkulku ja perheellistyminen (The woman's life course and the family formation). Population 1992, No. 1. Helsinki: Statistics Finland.

Notkola, Irma-Leena 1989. Luonnollisesta hedelmällisyydestä lapsirajoitukseen: mikrodemografinen tutkimus hedelmällisyyden transitiosta (From natural fertility to family limitation: a family reconstitution study of fertility transition in Finland). Publications of the Finnish Demographic Society, No. 12. Helsinki: Suomen Väestötieteen Yhdistys.

Observatoire Démographique Européen 1996. La fécondité en Suéde. L'Observatoire Démographique Européen vous informe, No.2. Paris.

Palli, Heldur. 1988. Otepää rahvastik aastail 1716-1799. Tallinn.

Palli, Heldur. 1997. Eesti rahvastiku ajalugu 1712-1799. Tallinn: Teaduste Akadeemia Kirjastus. 
Royal Ministry for Foreign Affairs. 1974. The biography of a people: past and future population changes in Sweden. Stockholm.

Sardon, Jean-Paul. 1990. Le remplacement des generations en Europe depuis le debut du siecle. Population 45(6):947-969.

Sardon, Jean-Paul and Gérard Calot. 1997. La reprise de la fécondité au milieu des anneés trente, phénomene non percu des observateurs du temps. L'Observatoire Démographique Européen vous informe, No.5. Paris.

Stankuniene, Vlada and Maré Baublyte. 1996. Lithuanian Family and Fertility Survey: standard tabulations and main data. Vilnius: Lithuanian Institute of Philosophy and Sociology.

Strömmer, Aarno 1969. Väestöllinen muuntuminen Suomessa (The demographic transition in Finland). Publications of the Population Research Institute, Series A, No. 13. Helsinki: The Population Research Institute.

Vishnevski, Anatoli and Andrei Volkov (ed.). 1983. Vosproizvodstvo naselenia SSSR. Moscow.

UN and ECE 1993. Fertility and family surveys in countries of the ECE Region: standard record files and standard country reports. Geneva: United Nations.

Zvidrins, Peteris. 1996. Gimene un Dzimstiba Latvija (1995 gada aptaujas galvenie rezultati) (ed.). Riga: Latvijas Universitates. 